\title{
IBM USAHA MIKRO PEMBUATAN TAHU TAKWA KUNING DAN STIK TAHU DESA TINALAN KECAMATAN PESANTREN KOTA KEDIRI
}

\author{
Ria Lestari Pangastuti1) Enni Sustiyatik2) \\ ${ }_{1}$ Fakultas Ekonomi Universitas Kadiri \\ Ceria.ria@gmail.com \\ ${ }_{2}$ Fakultas Ekonomi Universitas Kadiri
}

\begin{abstract}
Abstrak
Desa Tinalan Kecamatan Pesantren Kota Kediri merupakan sentral penghasil tahu di kota kediri. Hampir semua penduduk yang ada di Desa Tinalan Gang 4 tepatnya memiliki mata pencaharan yang sama yaitu sebagai pengrajin Tahu dan stik tahu. Mitra dalam IbM ini adalah Bapak Jamalidun dan Bapak Parman.

Dalam proses produksinya kedua mitra masih menggunakan peralatan yang ada saja dengan kapasitas yang belum bisa memenuhi kebutuhan pasar sehingga peluang kenaikan pasar belum bisa dimanfaatkan sepenuhnya oleh pengusaha mikro. Mitra pemasaran produk regional ada di kios milik mitra, pasar setempat, dan tengkulak. Permintaan yang makin tinggi di hari - hari tertentu, misalnya : liburan, hari besar dan hari raya membuat mitra tidak bisa memenuhi pasar. Pola manajemen yang diterapkan oleh mitra masih sangat sederhana sekali, tidak ada catatan rinci mengenai masuk dan keluarnya barang dan biaya yang dikeluarkan selama produksi sehingga tidak diketahui secara pasti jumlah keuntungan bersih dari hasil usahanya.

Dengan dilaksanakannya Program IbM ini diharapkan bisa berdampak pada perkembangan usaha mikro ini sehingga pola manajemen lebih baik sehingga mitra bisa mengetahui keuntungannya dengan pasti, dapat menciptakan lapangan kerja yang lebih besar sehingga mampu menyerap tenaga kerja di desa. Ini dapat dilihat dari telah maksimalnya produksi yang dilakukan oleh mitra, cara packing dan sistem pembukuan yang lebih baik dari biasanya, dan selain itu mitra telah terdaftar dalam HKI merek dagang.
\end{abstract}

Keyword : tahu takwa kuning, stik tahu, usaha mikro

\section{A. Pendahuluan}

Kondisi ekonomi UMKM saat ini dijadikan sebagai salah satu tulangpunggung ekonomi di Indonesia. Saat ini UKM dan koperasi memiliki sumbangan 56\% terhadap pertumbuhan ekonomi. Bila dilihat dari kontribusi UMKM yang cukup besar, maka perlu adanya pembangunan jangka panjang yang meliputi: (1) strategi yang berfokus pada peningkatan kualitas SDM, meningkatkan kapasitas pengetahuan dan teknologi penyerapan dan memperkuat keunggulan kompetitif ekonomi, (2 ) menciptkana lingkungan yang kondusif, memeberi hukum/regulasi serta mendukung UMKM, meningkatkan akses sumber dayaproduktif dengan memberikan fasilitas produksi modern, meningkatkan pengembangan produk dan akses pemasaran dengan membangun sarana dan prasarana yang memberikan 
kesempatan UMKM dan Koperasi, Peningkatan kualitas daya saing sumber daya manusia untuk mengatasi dengan usaha bisnis, penguatan pengembangan kelembagaan koperasi dan UMKM dengan memberikan advokasi dan bantuan teknis seperti : keterampilan manajerial, kematangan financial, akses pemasaran dan teknologi , (3) melaksanakan program framework mencakup output yang mencakup : a. Memberlakuan koperasi baru hukum, untuk mengembangkan koperasi didasrkan partisipasi anggota, b. Menetapkan peraturan pemerintah dan peraturan menteri sebagai pedoman rinci untuk memberdayakan koperasi dan UMKM, c. Menyediakan skema dana bergulir dengan membentuj lembaga keuangan untuk mendukung koperasi, d. Menyediakan skema kredit usaha rakyat (KUR) yang merupakan kredit khusus bagi UKM dan pengusaha baru dengan kerangkajaminan dari pemerintah, e. Mempromosikan produk koperasi dan UKM melalui fasilitas trading house (SMESCO) dalam pameran luar negeri.

Dari hasil program dan kebijakan untuk pengembangan UKM Indonesia menghasilkan beberapa kesimpulan diantaranya sumber daya manusia yang kompetitif koperasi dan UKM, memberikan akses keuangan inklusif, peningkatan koperasi dan UMKM secara kelembagaan, membentuk hasil produk yang kompetitif koperasi dan UMKM.

Salah satu UMKM yang merupakan mitra pengabdian masyarakat ini adalah pengusaha mikro pembuat tahu dan stik tahu yang ada di Desa Tinalan Kecamatan Pesantren Kota Kediri.

Tahu merupakan makanan khas dari kediri yang telah dikenal sejak dahulu dan sangat digemari oleh masyarakat. Yang salah satunya ada di desa Tinalan Kecamatan Pesantren Kota Kediri, yaitu sentral pembuatan tahu dan stik tahu yang telah dikenal luas oleh masyarakat kediri maupun luar kediri. Di desa Tinalan ada kurang lebih 31 pengusaha tahu rumahan atau yang disebut usaha mikro tahu. Usaha tahu dijadikan sebagai mata pencaharian utama oleh masyarakat Desa Tinalan khususnya gg.4 Kota Kediri.

Selain banyak variasi olahan yang bisa dihasilkan dari olahan tahu ini, limbah tahu juga bisa dimanfaatkan yang cair dimanfaatkan sebagai nata de soya seperti yang dituliskan oleh peneliti sebelumnya yaitu Rasita Purba,dkk dalam jurnalnya yang berjudul "IbM kelompok Usaha Tahu di kecamatan Lubuk Pakam”. Sedangkan untuk limbah padat biasanya dijual lagi untuk dimanfaatkan sebagai pakan ternak.

Nata de soya adalah selulosa yang mengandung air sekitar 98\% dengan tekstur kenyal, kokoh, putih, dan transparan dengan rasa yang mirip kolang-kaling. Produk ini dapat dipakai sebagai sumber makanan yang rendah kalori untuk keperluan diet dan mengandung serat yang sangat dibutuhkan dalam proses fisiologi (Cahyadi, 2009 dalam Rasita, dkk). 
Berikut ini adalah gambar produk yang dihasilkan oleh mitra kami dalam pelaksanaan pengabdian masyarakat ini.

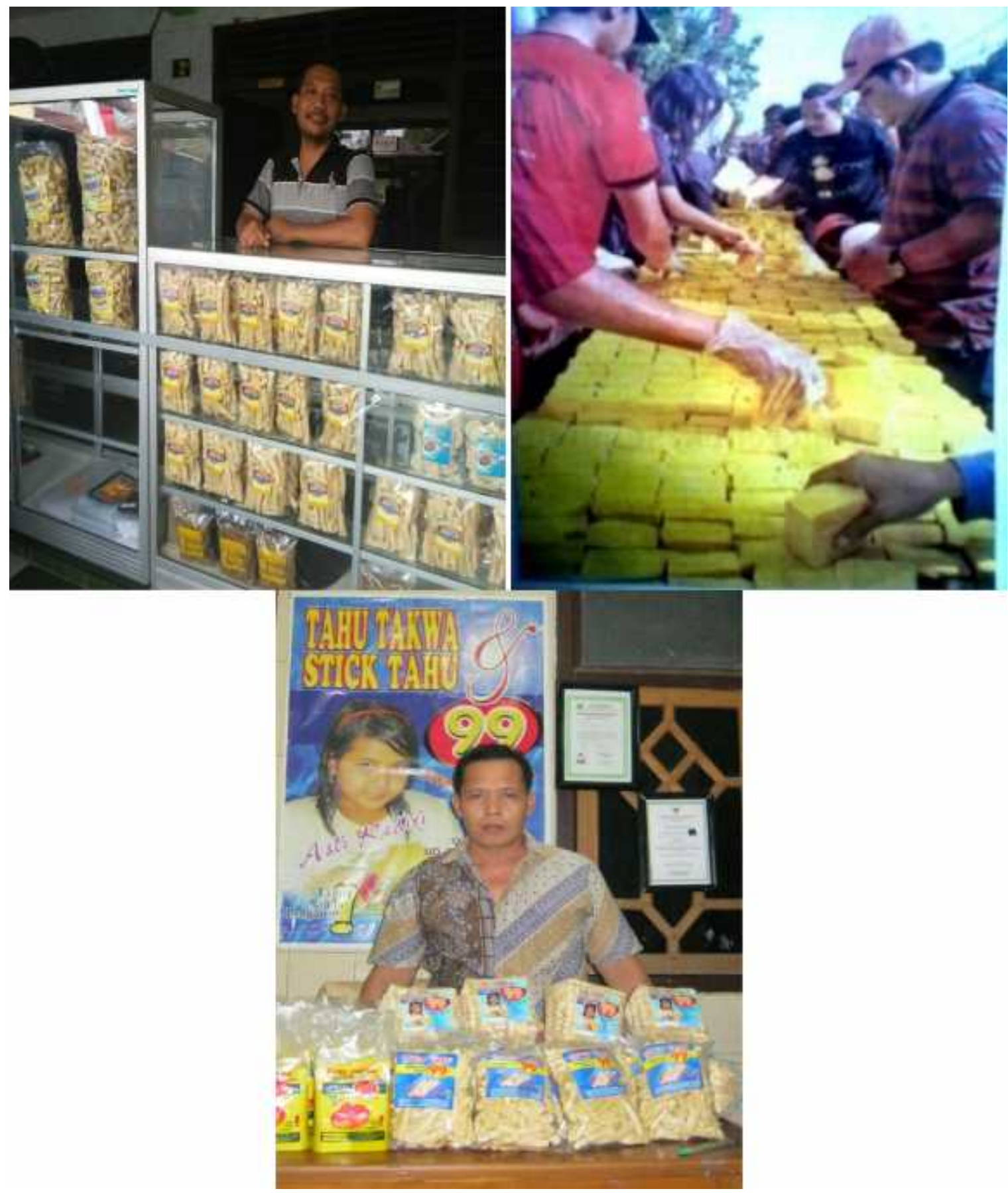

Di program Ipteks bagi Masyarakat (IbM) Usaha Mikro Pembuatan Tahu Takwa Kuning dan Stik Tahu Desa Tinalan Kecamatan Pesantren Kota Kediri kami memilih 2 mitra, yaitu : Usaha Mikro citarasa 99 dan Usaha Mikro Stik aman. Bapak jamaludin adalah pemilik dari usaha mikro citarasa 99 yang telah menekuni usaha ini sebagai mata pencaharian utama kurang lebih 25 tahun, sedangkan Usaha Mikro Stik aman adalah milik Bapak Parman. Olahan yang dihasilkan oleh kedua mitra kami adalah : Tahu takwa kuning, tahu takwa putih, 
stik tahu dan tahu kress/tahu bulat yang teksturnya renyah. Olahan ini dibuat sendiri oleh mitra kami dengan alur sebagai berikut :

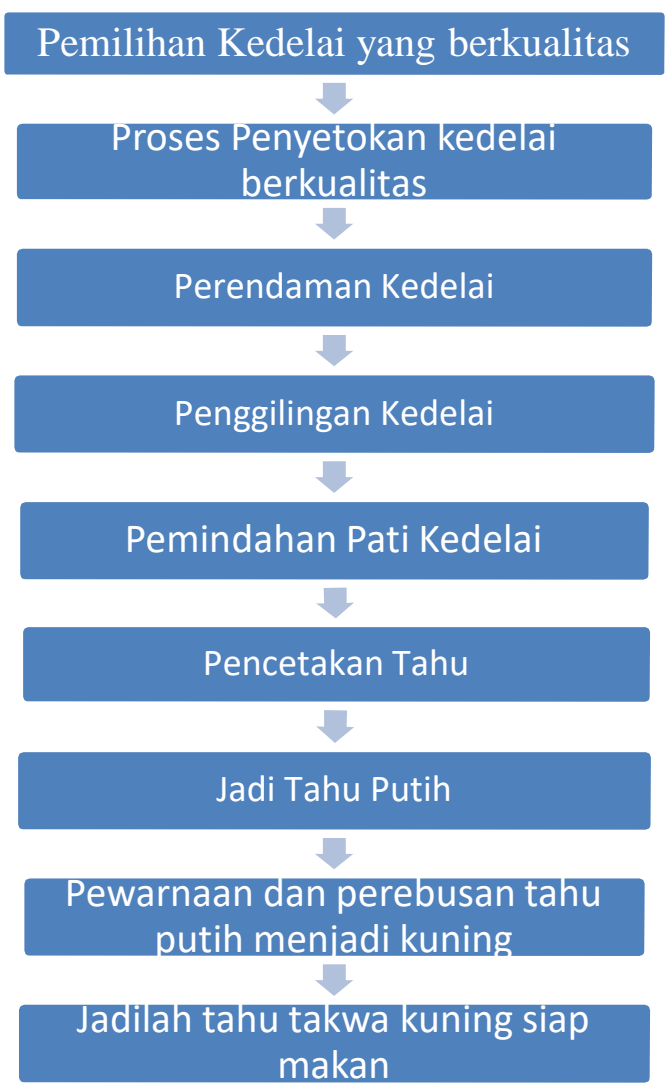

Berikut gambar prosesnya :
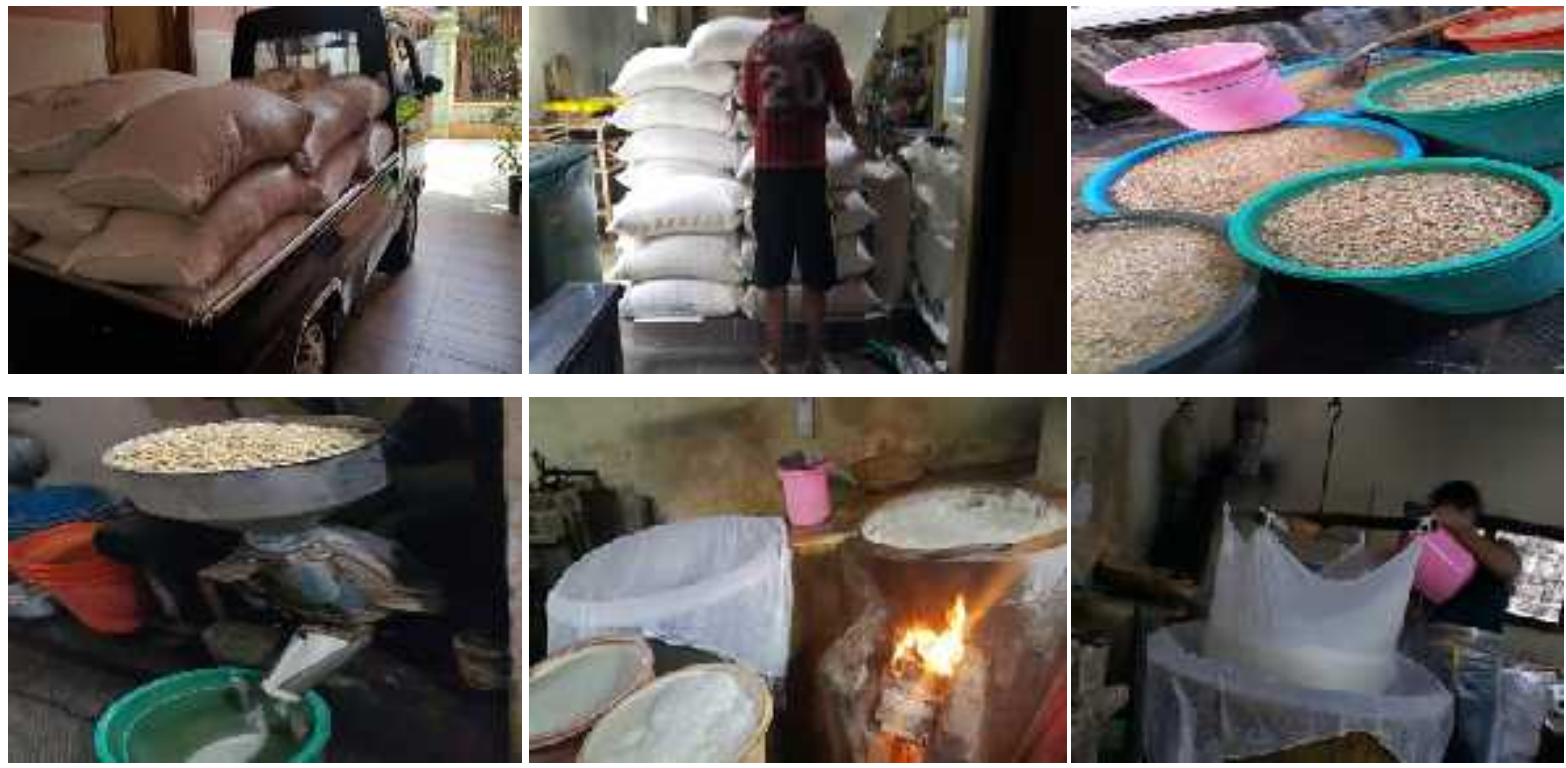

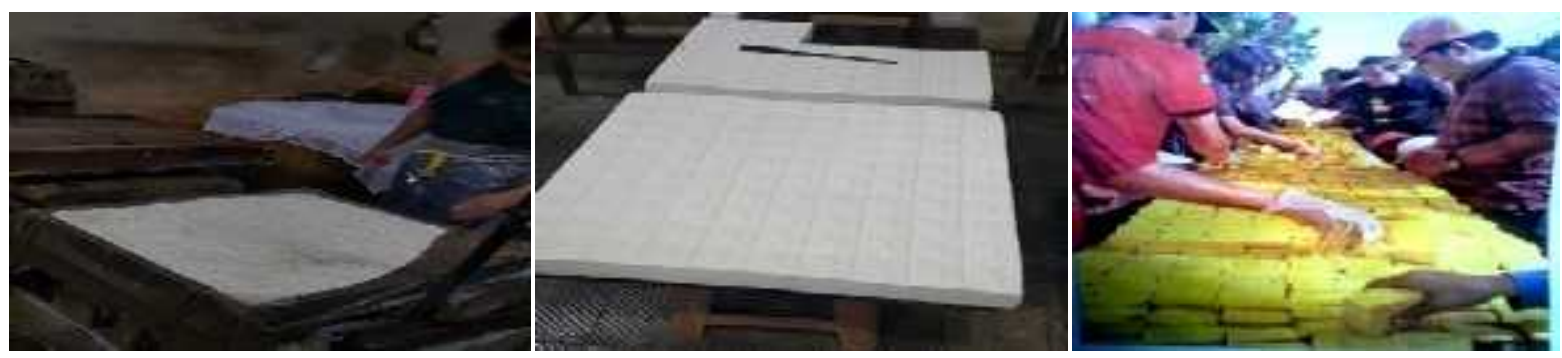

Untuk produksi mitra kami masih menggunakan alat seadanya, sedangkan untuk saat ini alat tersebut sudah tidak mampu lagi menampung kapasitas produksi dari mitra kami. Alat yang digunakan adalah sebagai beikut :
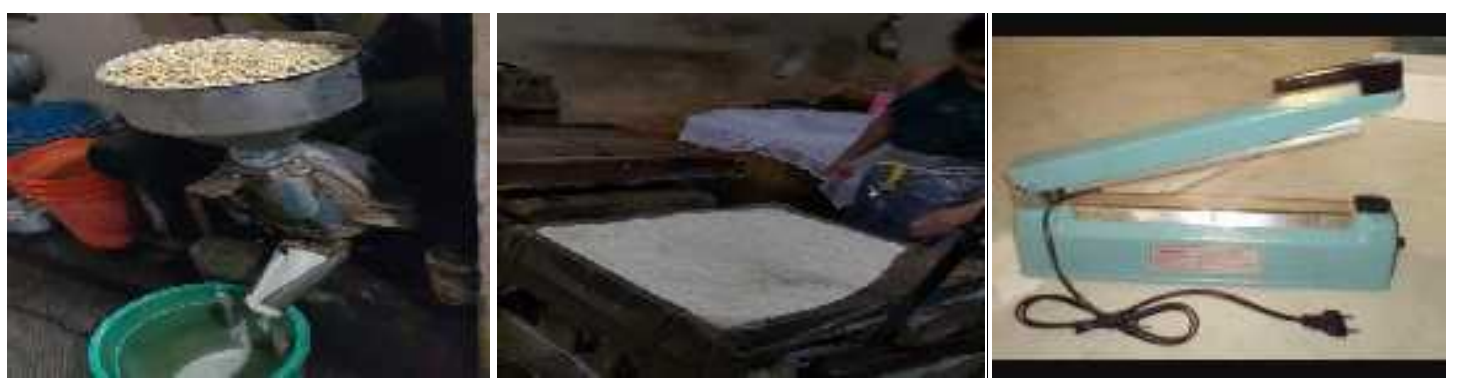

Alat penggiling yang ada pada gambar diatas ini telah digunakan kurang lebih sudah 25 tahun sehingga efektifitasnya sudah sangat menurun dan kapasitasnya juga kurang besar untuk digunakan saat ini. Untuk cetakan tahu yang dimiliki mitra kualitasnya sudah menurun jadi perlu diganti dengan cetakan yang baru agar tidak mempengaruhi kualitas tahu yang dihasilkan. Untuk proses packing mitra kami masih menggunakan alat packing biasa berupa sealer diatas, sealer seperti gambar diatas ini sangat rentan bocor. Jika terjadi kebocoran pada kemasan stik tahu, maka kualitas stik tahu akan turun dengan ciri rasa yang tengik dan kurang kerenyahannya.

Alur pembuatan stik tahu : 


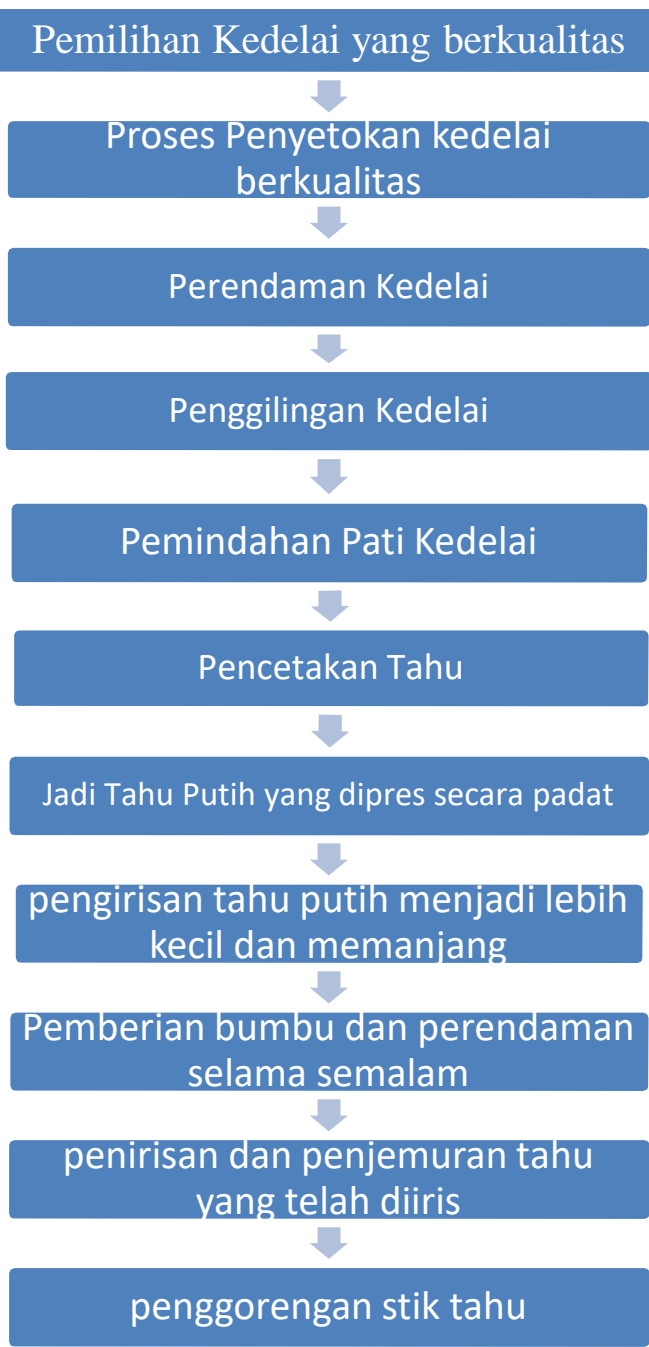

Dari gambaran tersebut dapat dilihat proses produksi yang dilakukan oleh kedua mitra masih sangat sederhana dengan tempat yang produksi yang sangat sempit. Tenaga kerja yang digunakan selama ini dari keluarga sendiri, karena mitra sangat sulit mendapatkan tenaga kerja yang sesuai dengan keinginan mitra.

Untuk stik tahu kendalanya adalah pada saat penjemuran memerlukan waktu yang cukup lama yaitu : 2-3 hari baru bisa dilakukan penggorengan. Bila musim penghujan penjemuran dibantu dengan oven tetapi stik tahu yang dihasilkan tidak terlalu bagus bila dibanding dengan penjemuran secara tradisional.

Dari segi pemasaran produk, kedua mitra selama ini tidak mengalami kesulitan karena produk yang dihasilkan kedua mitra sudah sangat dikenal di masyarakat desa Tinalan untuk khususnya dan Kota Kediri umumnya. Daerah pemasaran tahu dan stik tahu mitra adalah : 1. Gerai milik mitra yang ada di depan rumah

2. Pedagang Pasar Tradisional baik Pasar Pahing yang ada di Desa Singonegaran Kecamatan Pesantren juga ada di Pasar Wilayah Kediri. 
3. Pedagang Keliling Tukang Sayur yang setiap hari menjajakan sayur di masyarakat sekitar.

4. Pedagang Makanan, terutama yang ada di wilayah Kecamatan Pesantren.

5. Event - event yang ada di Kediri.

6. Restoran yang ada didaerah kediri, dengan adanya bantuan IbM mitra telah mampu menembus pasa restoran yang ada di Kediri. Produk mitra sudah mulai bisa diterima sesuai dengan kebutuhan restoran tersebut.

Mitra tidak memasarkan produknya di swalayan, karena perputaran uang yang diterima dirasa terlalu lambat.

Untuk waktu-waktu tertentu selain hari libur, hari besar nasional dan hari Raya penjualan mitra biasa saja, bahkan tak jarang penjualannya sepi dalam artian tidak ada lonjakan penjualan yang cukup tinggi. Disini mitra ingin dibantu untuk memperluas jaringan pemasarannya agar dihari biasapun penurunan pendapatan mitra tidak terlalu besar.

Pola manajemen yang diterapkan oleh kedua mitra masih sangat sederhana tidak ada pencatatan yang pasti terhadap setiap transaksi yang dilakukan oleh mitra, baik dari segi produksi maupun penjualan yang ada dikios mitra. Ini dikarenakan mereka hanya berfikir tentang keuntungan saat melakukan penjualan tanpa memperhitungkan biaya tenaga kerja. Mereka beranggapan tenaga yang dia keluarkan merupakan tanggung jawabnya demi mendapatkan keuntungan untuk memenuhi kebutuhan hidup sehari-hari. Jadi untuk perhitungan laba - rugi mereka hanya menggunakan perhitungan rata-rata dan belum ada perhitungan pasti tentang hal tersebut.

Beberapa temuan penulis yang didapatkan oleh penulis saat suvery di lapangan terhadap usaha kedua mitra, yaitu :

1. Tempat perendam stik tahu masih menggunakan bak plastik yang tingka sterilnya kurang bila dilihat dari sisi kekesahatn.

2. Proses packingnya masih sederhana yaitu menggunakan sealer manual yang rawan kebocoran, sehingga produk tidak tahan lama. Selain itu plastik yang digunakanpun juga masih menggunakan plastik biasa yang juga rawan bocor sehingga bisa membuat produk terasa tengik.

3. Pola manajemen yang kurang baik. Terutama pada pembukuannya belum ada sistem pencatatan yang terarah, sehingga mitra tidak bia memastikan keuntungannya.

4. Mesin penggiling yang digunakan sudah usang, karena mesin penggiling yang digunakan oleh mitra sudah berumur kurang lebih 25 tahun jadi secara efektifitas dan efisiensi kerja sudah berkurang sekali. 
5. rak dalam oven pengering krecek menggunakan kayu, dan ini sangat membahayakan keselamatan tenaga kerja. Dengan alasan kayu bisa jadi penghantar panas ini bisa menyebabkan kebakaran jika terjadi kelalaian saat produksi.

Alasan mitra mendirikan usaha ini adalah :

a. Pembuatan tahu ini dijadikan sebagai mata pencaharian pokok dari masyarakat sekitar.

b. Banyaknya permintaan terhadap produk baik untuk dikonsumsi sendiri maupun dijadikan oleh-oleh.

c. Meskipun sama - sama menghasilkan tahu, tetapi alat yang digunakan pun berbeda dengan kualitas. Jadi walaupun memiliki produk luaran yang sama tiap - tiap produsen tahu yang ada di Desa Tinalan Kecamatan Pesantren mempunyai pangsa pasar masing masing, sehingga tetap ada celah untuk meraup keuntungan.

d. Limbah padat yang dihasilkan masih dapat dijual untuk dijadikan pakan hewan ternak.

e. Dapat menciptakan lapangan kerja bagi masyarakat.

Peluang - peluang mitra dalam mengembangkan usaha tahu yaitu :

1. Permintaaan tahu oleh masyarakat yang terus meningkat, karena banyak memiliki variasi olahan yang disukai oleh seluruh lapisan masyarakat.

2. Adanya keinginan yang tinggi dari mitra untuk mengembangkan usaha tahu dan stik tahu agar kesejahteraan keluarga dan karyawan meningkat.

3. Pengembangan produk olahan tahu cukup banyak, sehingga kedepannya bisa jadi bahan pertimbangan oleh mitra dalam jangka panjang

4. Perluasan jaringan pemasaran mitra diharapkan bisa meningkatkan produksi.

\subsection{Permasalah yang dihadapi}

Berdasarkan hasil wawancara dengan mitra ada permasalahan yang dihadapi oleh mitra adalah sebagai berikut :

a. Alat penggiling kedelai dengan mesin dinamo, untuk alat penggilingan yang dipakai mitra sudah digunakan selama kurang lebih 25 tahun jadi kondisinya telah usang dan perlu pengganti alat baru agar produksi lebih efektif.

b. Tempat produksi mitra kurang memadai dan sempit, karena tempat produksi mitra jadi satu dengan rumah tinggal dan kios yang dijadikan sebagai tempat mitra menawarkan produknya.

c. Ada bantuan alat yang diberikan, tapi tidak sesuai dengan kebutuhan mitra sehingga tidak tepat guna. 
d. Alat pengepakan untuk stik tahu masih menggunakan sealer biasa. Padahal disini untuk menjamin kualitas stik tahu seharusnya mitra menggunakan mesin saeler otomatis, selain itu kantong plastik yang digunakan seharusnya adalah kantong plastik yang free BPA sehingga bakteri sangat sulit masuk yang bertujuan untuk menjaga kualitas produk.

e. Bak perendaman yang digunakan untuk merendam stik masih menggunakan bak plastik biasa, seharusnya untuk menjaga kebersihan dan kualitas makanan bak perendam yang digunakan terbuat dari stainless steel.

f. Pengetahuan mitra terhadap pembukuan yang masih kurang sehingga sulit untuk mengetahui pendapatan bersih dari pembuatan tahu dan stik tahu yang diperoleh mitra, uang hasil penjualan dari gerai pun tercampur menjadi satu juga sehingga tidak ada pemilahan.

g. Saat musim penghujan datang mitra kesulitan untuk menjemur krecek stik tahu sehingga mitra menggunakan oven rakitan sendiri yang kondisinya kurang memadai, secara kualitas juga kurang bagus.

h. Pengetahuan mitra mengenai manajemen pemasaran masih terbatas, karena kedepan tantangan dan persaingan usaha tahu semakin meningkat dan membutuhkan inovasi inovasi pemasaran.

i. Mitra belum mempunyai HKI merek dagang yang dikhawatirkan jika tidak memiliki HKI merek dagang pengusaha lain bisa dengan seenaknya menamai usaha mereka dengan nama yang sama atau menyerupai nama merek dagang mitra kami.

j. Tempat Parkir di Kios, dengan kondisi jalan depan kios mitra yang cukup sempit membuat konsumen yang membawa mobil kesulitan untuk memarkir mobilnya sehingga yang awalnya ingin membeli menjadi enggan untuk membeli.

\section{B. TARGET DAN LUARAN}

Target luaran dari pengabdian masyarakat di Desa Tinalan Kecamatan Pesantren Kota Kediri ini adalah sebagai berikut :

1. Alat penggilingan kedelai dan kapasitasnya akan disesuaikan dengan kebutuhan kedua mitra. Hal ini bertujuan untuk memperlancar proses produksi.

2. Alat untuk pengemasan stik tahu yang semula menggunakan saler biasa dapat digantikan dengan sealer otomatis. Hal ini bertujuan untuk mempercepat proses pengemasan dan dapat digunakan sebagai deteksi dini terhadap produk yang sudah tidak layak konsumsi. 
3. Dengan adanya alat penggilingan kedelai dan vacum sealer otomatis, diharapkan dapat membantu meningkatkan produksi tahu dan stik tahu yang kedepan dapat berpengaruh terhadap kenaikan omzet penjualan

4. Peningkatan pengetahuan mengenai pembukuan sederhana kedua mitra dengan memberikan pelatihan pencatatan keuangan sederhana. Selain menggunakan catatan keuangan sederhana, kedua mitra ingin memiliki sistem pembukuan yang menggunakan bantuan software pada komputer untuk mempermudah mitra dalam pengecekan stok dagangan dan suplier yang ingin menitipkan barang dagangannya kepada mitra.

5. Peningkatan pengetahuan manajemen pemasaran kepada kedua mitra untuk selalu melakukan pengembangan usaha. Manajemen pemasaran ini difokuskan pada penggunaan Word Of Mouth (WOM) dari pelanggan pada pelanggan lain dan juga penggunaan media sosial yang sedang marak dilakukan oleh kalangan bisnis saat ini. melalui media sosial yaitu Facebook, Instagram, website dan yang lainnya mitra melakukan promosi untuk memperluas jaringan pemasarannya.

6. Mendaftarkan merek dagang mitra ke direktorat Jenderal Hak Cipta Intelektual (HKI) agar merek dagangnya tidak dapat dipalsu oleh oknum yang tidak bertanggung jawab.

\section{METODE PELAKSANAAN}

Untuk mengatasi permasalahan yang dihadapi mitra yaitu pengusaha mikro pembuat tahu takwa kuning dan stik tahu di Desa Tinalan Kecamatan Pesantren Kota Kediri, dapat dilakukan sebagai berikut :

1. Memotivasi mitra untuk terus mengembangkan usahanya agar kedepan menjadi lebih besar dan mampu menciptakan lapangan pekerjaan baru bagi warga sekitar dan kota Kediri pada umumnya.

2. Memberikan motivasi kepada mitra untuk berinovasi terhadap produk yang dihasilkan agar bisa menambah variasi olaha tahu.

3. Memberikan pelatihan cara penggunaan dan perawatan alat penggilingan yang benar agar bisa digunakan dalam jangka waktu panjang.

4. Memberikan pelatihan kepada mitra cara penggunaan dan perawatan vacum sealer yang benar agar bisa digunakan dan dimanfaatkan dalam jangka waktu panjang.

5. Memberikan pelatihan pembukuan yang baik kepada mitra agar kedepan mitra bisa menganalisis laba rugi usahanya. Melakukan pendampingan dalam penggunaan software yang telah diberikan kepada kedua mitra. 
6. Memberikan pelatihan bidang pemasaran dengan memanfaatkan teknologi saat ini untuk memperluas wilayah pemasaran dan menaikkan omset penjualan. Selalu melakukan pendampingan kepada mitra terhadap bagaimana cara mitra memanfaatkan media sosial sebagai media promosi mereka

Selama pelaksanaan pengabdian masyarakat ini, mitra akan menyediakan tempat dan bahan baku berupa kedelai sesuai dengan standar yang mitra pakai. Selain itu mitra juga akan menyediakan tempat untuk pelatihan - pelatihan yang akan dilaksanakan selama kegiatan pengabdian masyarakat ini.

Prosedur kerja :

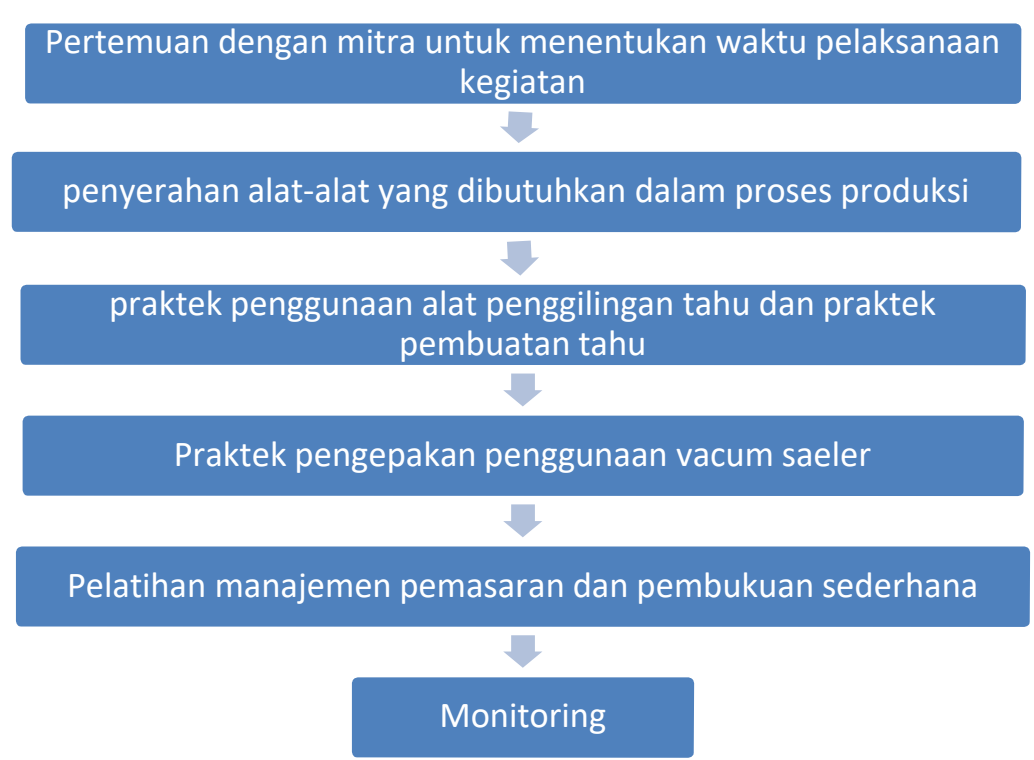

\section{HASIL YANG DICAPAI}

Beberapa kegiatan pengabdian masyarakat yang telah dicapai selama ini adalah :

1. Pertemuan dengan kedua mitra untuk menjadwalkan pelaksanaan kegiatan dengan kesepakatan sebelumnya di lokasi usaha mitra.

2. Survey tempat pembelian alat-alat produksi yang akan diberikan kepada mitra, serta membicarakan spesifikasi yang diinginkan apakah ada perubahan dari proposal yang telah diajukan.

3. Penyerahan alat - alat produksi yang akan diberikan kepada kedua mitra, antara lain : 1 set mesin penggiling kedelai lengkap dengan tangki air, 2 bak perendam stik stainlestil, vacuum sealer semi otomatis untuk packing, dan timbangan digital kapasitas $30 \mathrm{~kg}$ dengan foto sebagai berikut : 

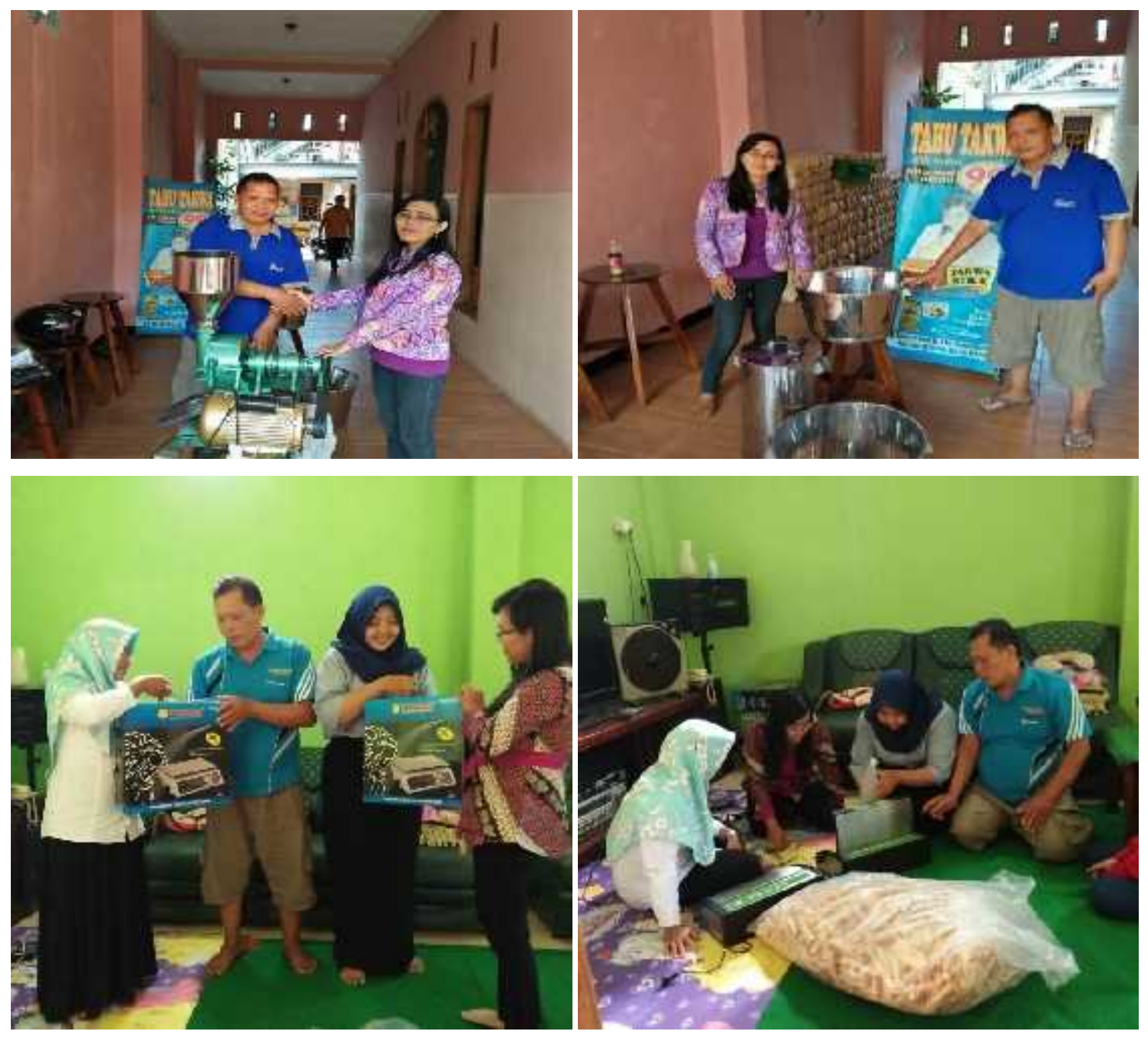

\section{Praktek penggunaan alat}

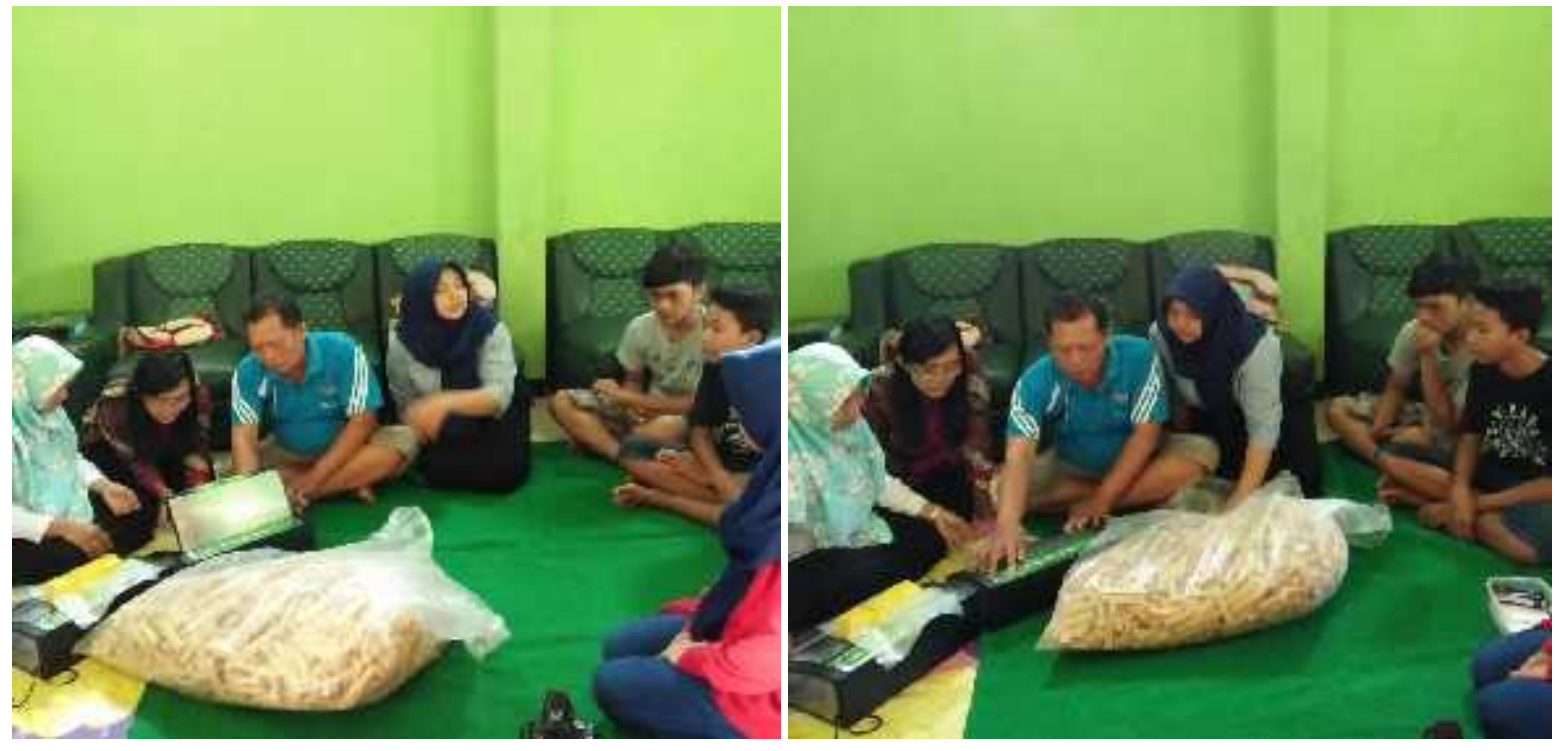


4. Pelatihan Manajemen Pemasaran, Pembukuan dan Business plan
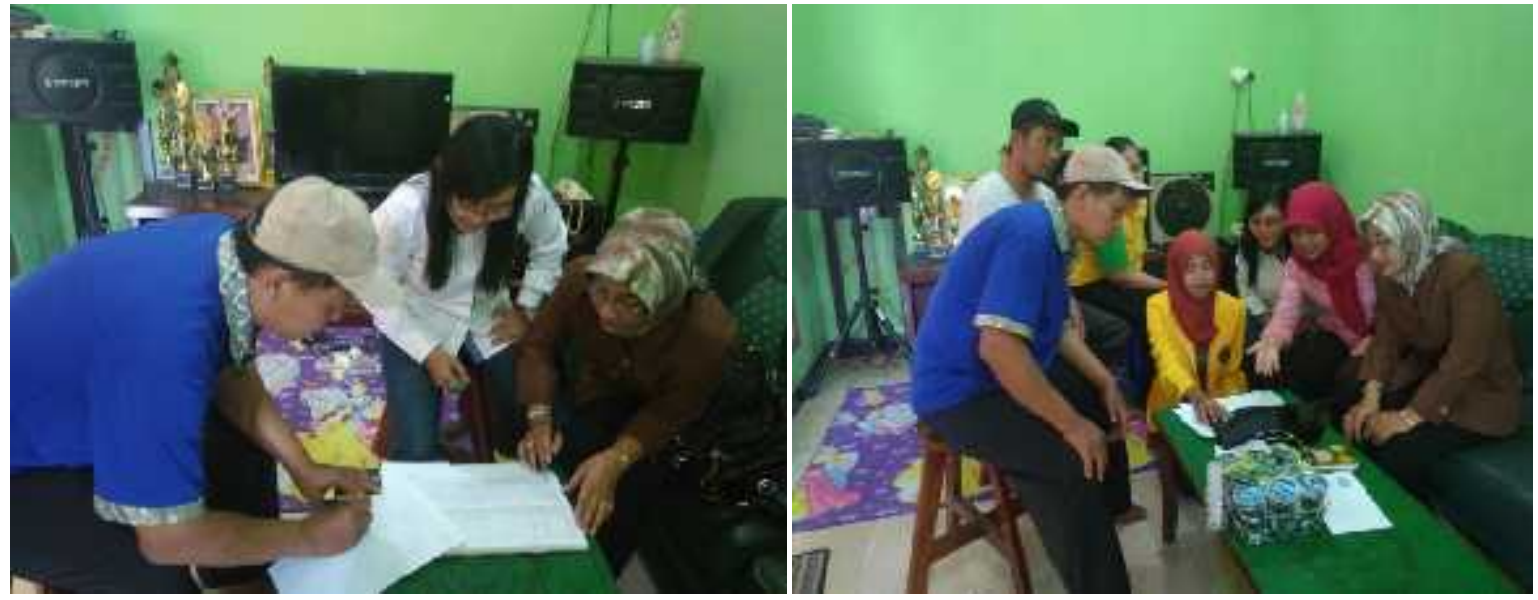

3. Penyerahan bukti pendaftaran merek dagang kepada mitra

Berikut ini adalah foto pengusul saat mendaftarkan merek dagang mitra dan mengambil bukti daftar merek dagang mitra di Direktorat Jenderal Hak Cipta Intelektual (HKI) yang ada di Surabaya.
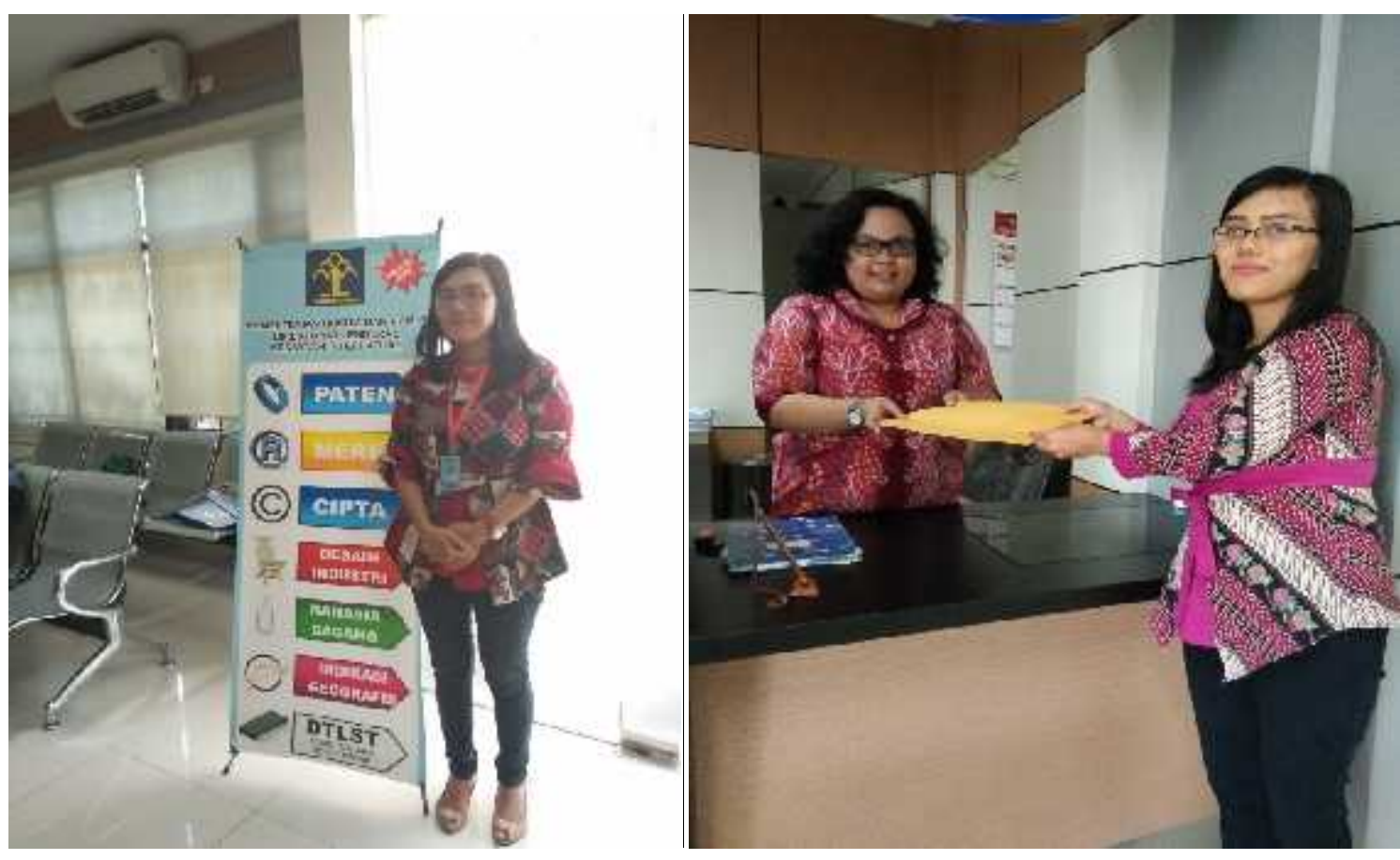

\section{Oven pengering krecek stik tahu}

Ini adalah foto oven rakitan yang telah diperbaiki melalui dana yang diberikan dari pelaksanaan IbM ini. oven ini sangat membantu dalam mengeringkan krecek stik tahu khususnya saat musim penhujan yang sangat minim panas matahari. 

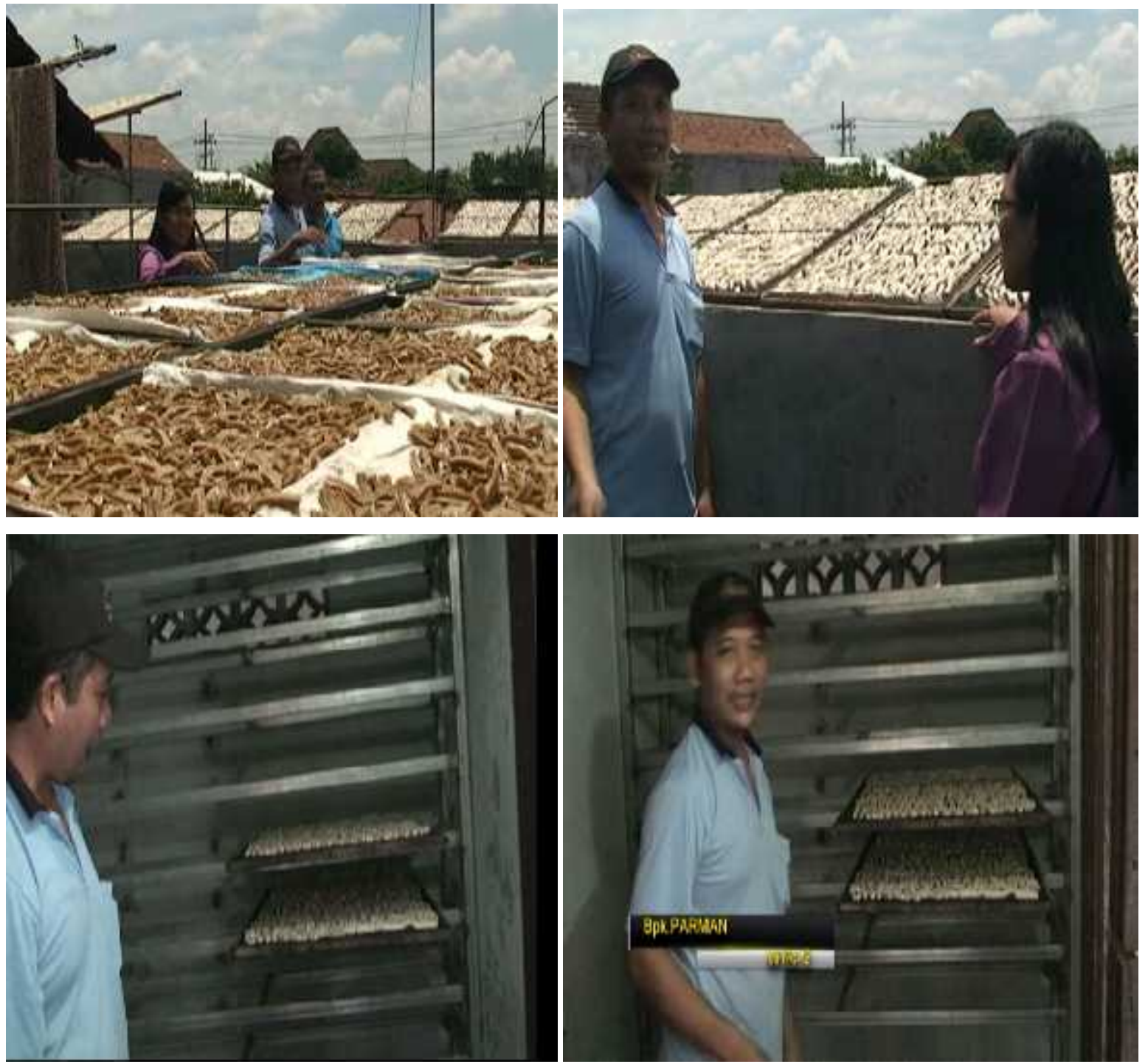

Sebelum dimasukkan kedalam oven tahu yang telah dipotong harus dikurangi kadar airnya dengan cara dijemur sebentar, barulah setelah itu krecek tahu yang kadar airnya sudah berkurang tadi dimasukkan ke dalam oven pengering krecek untuk dikeringkan.

\section{E. RENCANA TAHAPAN BERIKUTNYA}

Untuk rencana kegiatan selanjutnya adalah pelatihan pembukuan sederhana yang disesuaikan dengan produk dan kemampuan mitra serta pelatihan pemasaran agar kedepannya akan lebih baik dan mempunyai daerah pemasaran yang lebih luas. Selain itu akan diadakan pendampingan dan pemantauan produksi. Dan kedepan rencananya ada perubahan terhadap kios digunakan mitra untuk berjualan yang ada di area produksi. Yang dulunya kios ini dinamai "PUSAT OLEH-OLEH 99 KHAS KEDIRI" diganti nama menjadi "PUSAT OLEH-OLEH DAN EDUKASI 99 KHAS KEDIRI". 
Dengan pertimbangan seringnya tempat usaha bapak jamaludin ini digunakan oleh sekolah-sekolah yang ada dikediri maupun diluar kota kediri untuk melihat langsung cara pembuatan tahu takwa kuning dan stik tahu khas kota kediri. Diharapkan dengan adanya perubahan ini juga dapat berdampak positif terhadap penjualan produk tahu untuk pak jamal dan pak parman khususnya dan untuk pengusaha tahu di Desa Tinalan Kecamatan Pesantren Kota Kediri umumnya.

\section{F. KESIMPULAN DAN SARAN}

\section{KESIMPULAN}

Dengan adanya bantuan ipteks bagi masyarakat ini diharapkan kedepan usaha mikro ini makin berkembang dan berdampak kepada kesejahteraan masyarakat dengan adanya lapangan kerja yang baru. Untuk mencapai ini semua mitra perlu mendapatkan dukungan dari pemerintah desa dan dinas terkait agar mitra tetap mempunyai motivasi untuk mengembangkan diri.

Dengan adanya rencana inovasi tempat usaha yang dilakukan oleh pak jamaludin diharapakan dapat berdampak kepada kesejahteraan mitra khususnya dan juga kesejahteraan warga sekitar lingkungan tersebut. Lapangan pekerjaan bertambah, pengangguran berkurang.

\section{SARAN}

Mitra dapat mengembangkan produksinya dengan menggunakan TTG (Teknologi Tepat Guna) yaitu Ketel. Bila memakai ketel proses pemasakan lebih cepat dan rasa lebih enak. Selain itu untuk penyaringan seharusnya juga menggunakan TTG alat penyaring otomatis yang terbuat dari stenlistill, sehingga tenaga untuk memasak lebih ringan. Untuk tenaga kerja seharusnya mitra mempunyai 1 tenaga kerja tetap yang diberikan keahlian mengolah kedelai menjadi tahu. Tenaga kerja yang sudah ada selama ini bukan merupakan pekerja tetap sehingga terkadang bila diperlukan pekerja tidak bisa membantu produksi ini membuat kedua mitra kesulitan mencari tenaga kerja ahli memasak tahu.

Dari segi olahan mitra juga masih dapat mengembangkan usaha dengan menciptakan trobosan olahan tahu lain dengan memanfaatkan bahan dasar yang ada di sekitarnya.

\section{G. DAFTAR PUSTAKA}

http://www.seputarukm.com/, diakses 27 Mei 2016 